\title{
Humidity Responses and the Role of Hamann's Organ of Cavernicolous Bathysciinae (Coleoptera Catopidae)
}

\author{
by \\ Marco LUCARELLI* and Valerio SBORDONI*,**
}

\section{INTRODUCTION}

Humidity plays a significant role in cave ecology and, consequently in the evolution of terrestial troglobites. Eye, pigmentation or wing structural rudimentation processes that are typical of the troglobitic life patterns in these organisms are accompanied by "progressive" modifications in various sense organs that tend to specialise and optimise their specific functions under particular selective pressures of the cave environment. It is, therefore, presumable that the hygroreceptors in terrestial troglobites are particularly efficient. However, little research into either hygroreceptors or humidity response has been carried out so far.

Argano, Sbordoni and Cobolli Sbordoni (1969) reported on the humidity response of Bathysciinae at different levels of specialisation (Bathysciola derosasi, Bathysciola sisernica, Leptodirus hohenwarti, Astagobius angustatus). This was the first experimental study to be carried out on comparative humidity responses among terrestial troglobites. Later, Bull and Mitchell (1972) studied the responses of two unrelated species of diplopods to various temperature and humidity gradients.

Complex sense organs exist on the 7th, 9th and 10th antenna segments of Catopidae family coleopterans. These structures, which are now collectively known as "Hamann's organ" (previously reported as "olfactory vesicle"), were first studied under the optical microscope by Jeannel (1911) and later under the electron microscope by Baccetti and Sbordoni (1967), by Corbière-Tichané (1974), by Peck (1977) and by Accordi and Sbordoni (1978). What is being dealt with is an aggregation of sensilla of various kinds cribrose-utricular,

* Institute of Zoology - University of Rome, Viale dell'Universita 32,00100 Roma, Italy.

** To whom reprint requests should be addressed. 
cribrose-stick, star shaped, claviform and trichoid gathered within the periarticular gutter and deeply invaginated vesicles in the cuticle.

Complexity and number of sensilla in Catopids of the Bathysciinae subfamily and Ptomaphagus (Eucatopinae) genus seem to be clearly proportional to the degree of specialisation for cave environments (Jeannel, 1911; Sbordoni and Cobolli Sbordoni, 1973; Peck, 1977). Nothing is known about how these structures actually work, an olfactory function having generally been attributed to them in the past even though Argano et al. (1969) prospected their possible role in hygroreception.

The purpose of our research was to test the hypothesis that the humidity response in Bathysciinae is all, or in part, controlled by the sense organs present on the 7 th, 9 th and 10th antenna segments. Consequently, we used two species (Bathysciola derosasi and Leptodirus hohenwarti), two troglobites that typify two distinct levels of morpho-physiological specialisation. In particular, the two species show different degrees of antennal organ complexity.

Humidity response in the two species studied was evaluated in four separate relative humidity conditions. In all cases the response of integral subjects was compared to the response of subjects which had been antennectomised below the 7 th antenna segment. In one of the species (Leptodirus hohenwarti) the response of subjects antennectomised above the 7th antenna segment was evaluated to determine the role of any eventual hygro receptors on the 9th and 10 th antennal segments.

\section{MATERIAL AND METHODS}

The Bathysciola derosasi subjects were gathered from the Patrizi, or Sasso, Cave near Cerveteri (Rome). The species had been previously introduced there in 1952 (Patrizi, 1956). The Leptodirus hohenwarti were gathered from the Noé Cave near Aurisina (Trieste), the typical locality for the reticulatus subspecies. Particular precautions were taken in gathering, transporting and raising the sample subjects (Sbordoni and Cobolli, 1969). In both caves the humidity levels where the samples were gathered were near saturation (98100\% Relative Humidity, R.H.).

Choice-chambers with two alternative conditions of relative humidity like those described by Gunn and Kennedy (1936) and previously used in experiments on Bathysciinae (Argano et al., 1969) were used for the experiments. The chambers consisted of circular ceramic dishes $15 \mathrm{~cm}$ in diameter and $3 \mathrm{~cm}$ in height. Each dish was divided into two equal compartments by a ceramic partition. Two solutions capable of establishing different relative humidity percentages were introduced into the two compartments. Each dish was covered by a copper screen $(40 \mathrm{mesh} / \mathrm{cm}) 17 \mathrm{~cm}$ in diameter. This screen constituted the "arena" on which the samples to be examined moved. Half a petri dish $15 \mathrm{~cm}$ in diameter and $1.5 \mathrm{~cm}$ high was used as the lid to the dish. A $1-\mathrm{cm}$ diameter hole was opened in the middle of each lid so that the subjects could be introduced into the chamber, the circular aperture being closeable with a 
cork stopper. Canvass adhesive tape was used to seal the lid to the dish in such a way as to make it air-tight.

Various aqueous concentrations of $\mathrm{H}_{2} \mathrm{SO}_{4}$ were used to control humidity levels. Beginning with $95-97 \%$ solution and 1.84 specific gravity, dilutions were prepared with distilled water according to Buxton and Mellanby's technique (1934). Dilutions were varied slightly so as to obtain the required specific gravity as differences had been noted in the various lots of $\mathrm{H}_{2} \mathrm{SO}_{4}$ supplied. In this way maximum deviations were kept down to $5 \%$ with respect to the desired degree of relative humidity. Solutions were prepared and introduced into the humidity chambers 15 hours before starting the experiments proper. Checks on humidity levels attained were carried out with Lambrecht hair hygrometers in containers like those described by Buxton and Mellanby (1934).

One hour before beginning the experiment proper, the subjects were placed in chalk-bottomed crystallisers so as to remove any traces of water on their integuments. Antennectomy was performed with micro-scissors after the insects has been cooled and, as a result, immobilised. The experiments on Leptodirus were carried out in $6^{\circ} \mathrm{C}$ thermostated chambers while those on Bathysciola occurred at $13^{\circ} \mathrm{C}$.

Humidity response experiments were conducted subjecting the insects to four relative humidity alternative conditions: $20-100 \%, 50-100 \%, 90-100 \%$, $50-90 \%$ and $100-100 \%$ control condition.

5 insects were used per experiment per choice-chamber. Besides the control, from 2 to 5 replications were run at the same time. Readings were taken every minute and the subjects' positions in one of the two dish sectors and their locomotive, activity or inactivity were recorded. Each test was run for $2 \mathrm{hrs}$.

The response level (reaction intensity) for every 10 minute period was given by Pielou and Gunn's formula (1940):

$$
\mathrm{I}=\frac{100(\mathrm{~W}-\mathrm{D})}{(\mathrm{W}+\mathrm{D})}
$$

where $\mathrm{W}=$ number of subjects in the more humid zone and $\mathrm{D}=$ number of subjects in the drier zone. In all, the experiments examined the reactions of 370 subjects giving a total of 44,400 position records, control subjects excluded. Table 1 summarises the experiments conducted.

\section{RESULTS}

1) Comparison between humidity reactions in Bathysciola derosasi and Leptodirus hohenwarti.

Comparing the reactions between experiment subjects and control subjects, a marked positive response to a humidity stimulus in integral (non-antennectomised) subjects of the two species evaluated may be seen. Response significance, $\mathrm{P}$, is considerable (Table 2). 
M. LUCARELLI AND V. SBORDONI

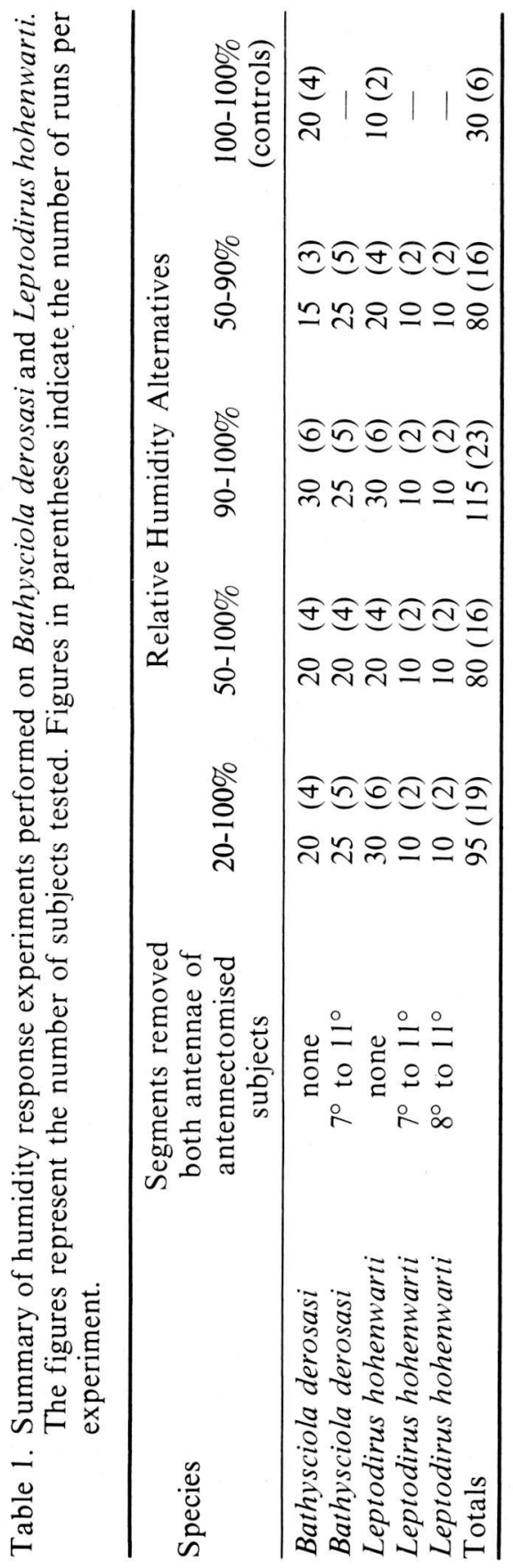


Table 2. Significance, $\mathrm{P}$, of $B$. derosasi and $L$. hohenwarti humidity responses at various R.H. alternatives.

$t$ estimated on the difference of the mean values of reaction intensity from controls (100-100\%) calculated every 10 minutes on the basis of 4-5 runs.

\begin{tabular}{ccccc}
\hline $\begin{array}{c}\text { R.H. } \\
\text { alternatives } \\
(\text { in \%) }\end{array}$ & \multicolumn{2}{c}{$\begin{array}{c}\text { B. derosasi } \\
\text { vs controls }\end{array}$} & \multicolumn{2}{c}{$\begin{array}{c}\text { L. hohenwarti } \\
\text { vs controls }\end{array}$} \\
\cline { 2 - 5 } & $\mathrm{t}$ & Significance & $\mathrm{t}$ & Significance \\
\hline $20-100$ & 17.408 & $\mathrm{P}<0.001$ & 8.742 & $\mathrm{P}<0.001$ \\
$50-100$ & 24.686 & $\mathrm{P}<0.001$ & 5.147 & $\mathrm{P}<0.001$ \\
$90-100$ & 12.587 & $\mathrm{P}<0.001$ & 4.557 & $\mathrm{P}<0.001$ \\
$50-90$ & 10.548 & $\mathrm{P}<0.001$ & 6.566 & $\mathrm{P}<0.001$ \\
\hline
\end{tabular}

Subjects were seen to be sensibly active during experiments. There appeared to be no significant correlation between the subject's level of activity and its position in the drier or more humid part of the humidity chamber. The graphs display our results synthetically. The curves plotted on the basis of average values taken from the various runs of the same experiment illustrate how reaction intensity varies with time.

The slope along the first stretch of the curve $(0-10 \mathrm{~min})$ indicates how rapidly the subject reacts to the stimulus intensity from the moment it is introduced into the chamber. The statistic reliability of these values is expressed by the confidence limits which are also derivable from the graph. Student's formula at $95 \%$ probability was used to calculate the confidence limits. In both species, reaction intensity and variance are proportional to the intensity of the negative stimulus (the difference between the two relative humidities).

The $90-100 \%, 50-100 \%, 20-100 \%$ alternative humidity chambers offer optimal environments in the more humid part and increasingly unfavourable conditions in the drier part. Experiments show that the lower the humidity level in the drier zone the more rapidly and decidedly the species respond. No substantial differences would appear to exist between the reactions of the two species. However, the Leptodirus seem to respond more gradually than the Bathysciola in relation to stimulus intensity, i.e. to the extremes in relative humidity just as Argano et al. noted (1969). This difference is particularly evident in comparing the relative reactions within the first 10 minutes of activity in the chamber.

2) The role of Hamann organ in humidity reactions.

Experiments conducted on Leptodirus reveal that insects antennectomised below the 7 th antenna segment, where the most conspicuous sense organs are located, exhibit virtually no capacity to react to humidity. Their reactions in the various relative humidity situations do not differ substantially from those 
Bathysclola derosasl
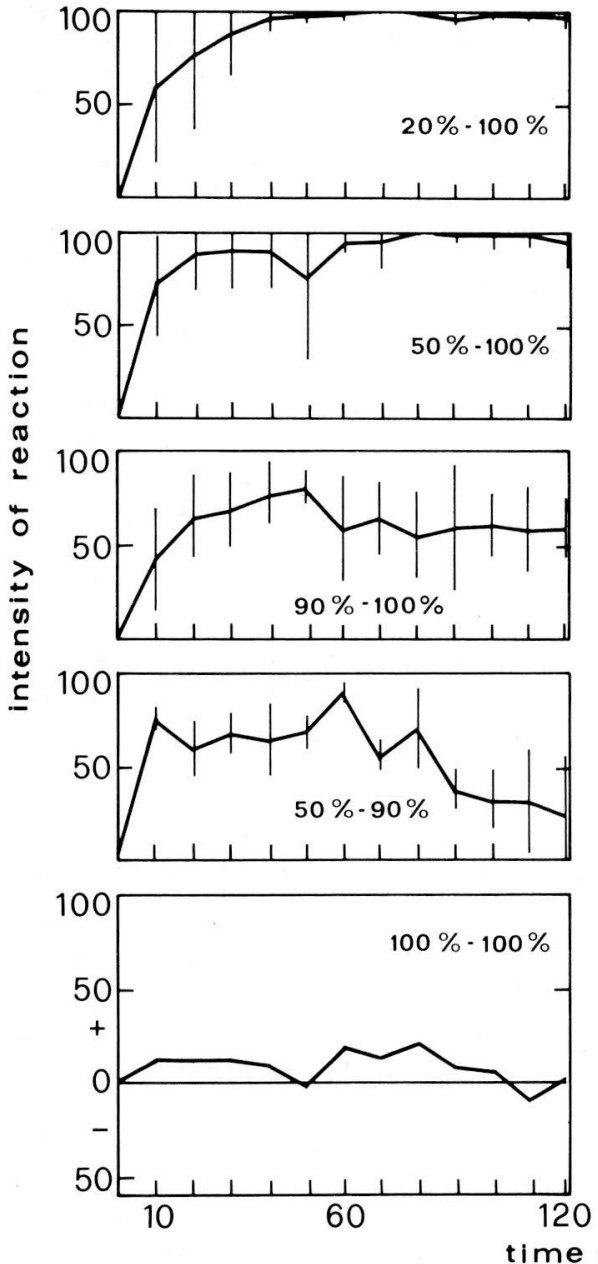

Leptodirus hohenwarti
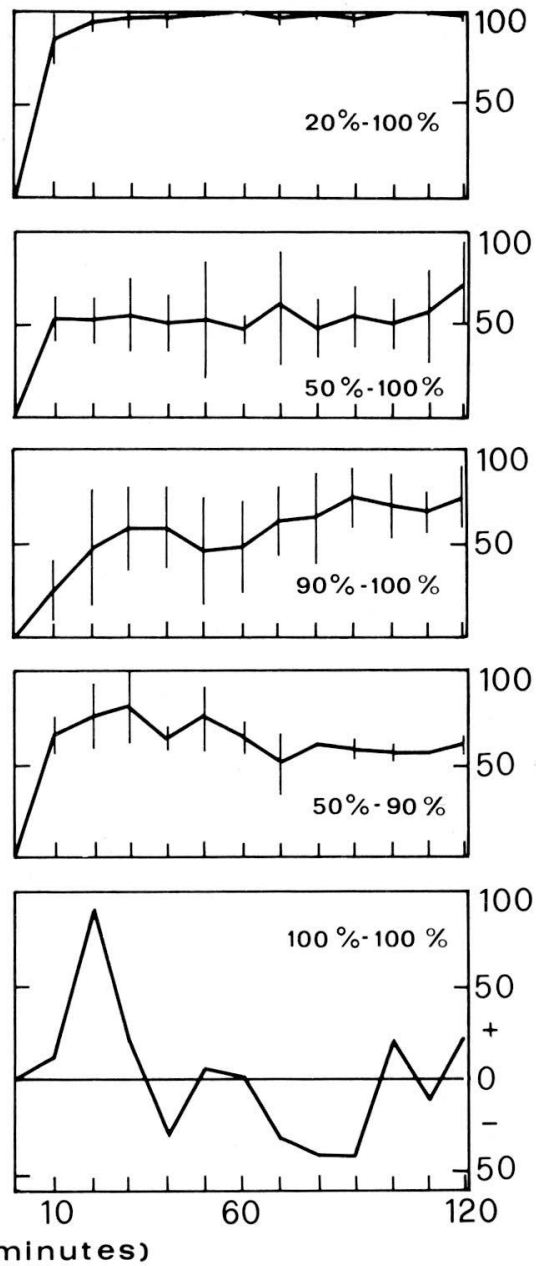

Fig. 1. Bathysciola derosasi and Leptodirus hohenwarti responses to different choice-chamber relative humidity alternatives. The results are expressed as the average number of individuals recorded on the moist side of the choice-chamber. Vertical lines represent the $95 \%$ confidence limits calculated from 4-5 runs.

observed under control conditions (Table 4). The fact that the curves are generally positive may be attributed to the subject's reduced locomotive speed in the damp zone due to orthokinetic-type mechanisms (Fraenkel and Gunn, 1961; Pertunnen, 1973). Reaction intensity does not increase progressively and in proportion to stimulus intensity as occurs with integral subjects. 


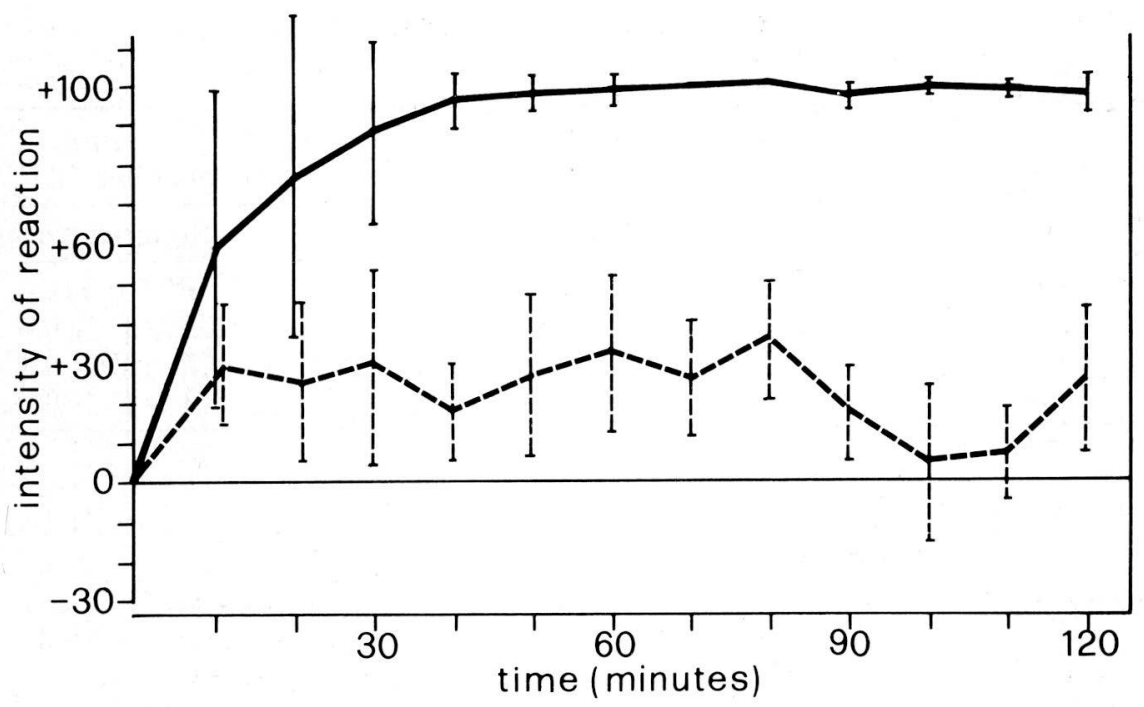

Fig. 2. Responses of intact (solid line) and antennectomised (broken line) $B$. derosasi to choicechamber $20-100 \%$ R. H. alternatives.

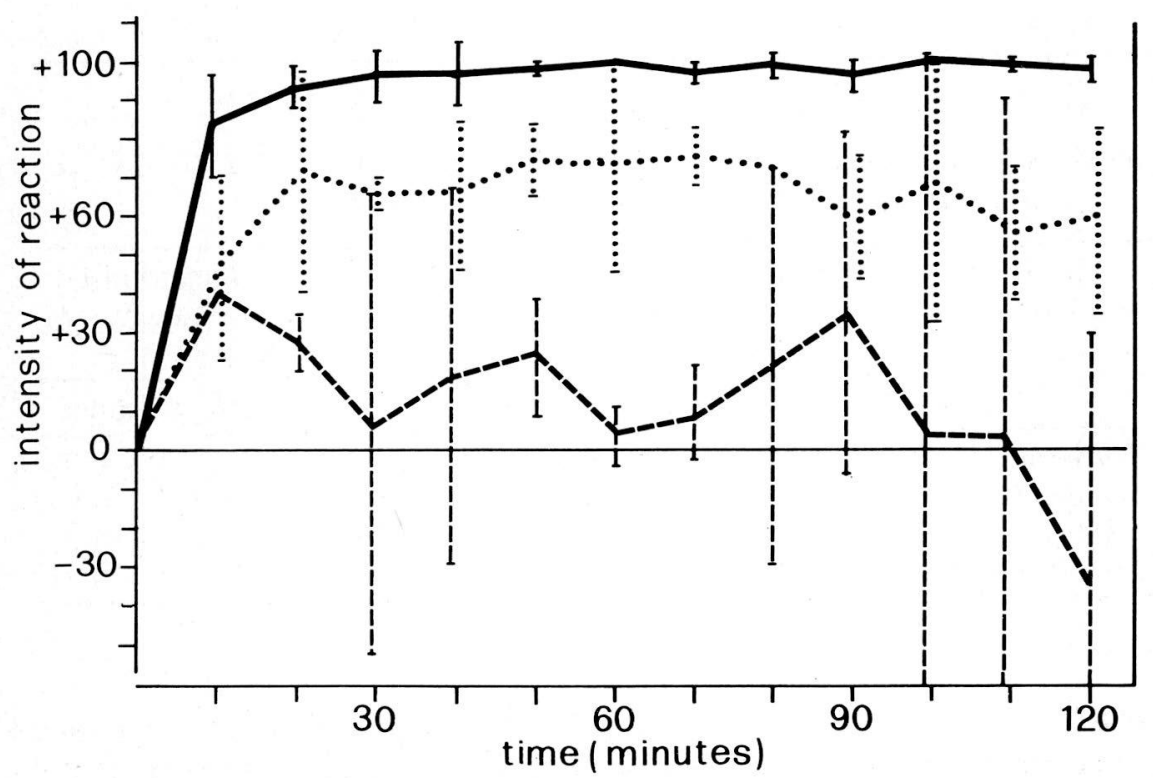

Fig. 3. Responses of intact and antennectomised L. hohenwarti to choice-chamber $20-100 \%$ R.H. alternatives. Solid line: intact subjects, broken line: subjects antennectomised below 7 th segment; dotted line: subjects antennectomised above 7 th segment. 
Table 3. Significance, $P$, of the humidity responses of intact and antennectomised $B$. derosasi.

\begin{tabular}{ccccc}
\hline $\begin{array}{c}\text { R.H. } \\
\text { alternatives }\end{array}$ & $\begin{array}{c}\text { Antennectomised subjects } \\
\text { vs intact subs. }\end{array}$ & $\begin{array}{c}\text { Antennectomised subs. } \\
\text { vs control subs. }\end{array}$ \\
\cline { 2 - 5 }$($ in $\%)$ & $\mathrm{t}$ & Significance & $\mathrm{t}$ & Significance \\
\hline $20-100$ & 13.282 & $\mathrm{P}<0.001$ & 7.182 & $\mathrm{P}<0.001$ \\
$50-100$ & 15.986 & $\mathrm{P}<0.001$ & 0.712 & $0.5>\mathrm{P}>0.4$ \\
$90-100$ & 21.185 & $\mathrm{P}<0.001$ & 1.515 & $0.2>\mathrm{P}>0.1$ \\
$50-90$ & 8.131 & $\mathrm{P}<0.001$ & 0.577 & $0.9>\mathrm{P}>0.5$ \\
\hline
\end{tabular}

Table 4. Significance, $\mathrm{P}$, of the humidity responses of intact L. hohenwarti and subjects antennectomised below the 7 th segment.

\begin{tabular}{ccccc}
\hline $\begin{array}{c}\text { R.H. } \\
\text { alternatives } \\
\text { (in \%) }\end{array}$ & $\begin{array}{c}\text { Subjects antennectomised } \\
\text { below 7th segment } \\
\text { vs intact subs. }\end{array}$ & $\begin{array}{c}\text { Subjects antennectomised } \\
\text { below } 7 \text { th segment } \\
\text { vs control subs. }\end{array}$ \\
$20-100$ & 12.907 & $\mathrm{P}<0.001$ & 0.930 & $0.4>\mathrm{P}>0.2$ \\
$50-100$ & 7.039 & $\mathrm{P}<0.001$ & 1.604 & $0.2>\mathrm{P}>0.1$ \\
$90-100$ & 5.315 & $\mathrm{P}<0.001$ & 1.515 & $0.2>\mathrm{P}>0.1$ \\
$50-90$ & 10.733 & $\mathrm{P}<0.001$ & 1.029 & $0.4>\mathrm{P}>0.2$ \\
\hline
\end{tabular}

Table 5. Significance, $\mathrm{P}$, of the humidity responses of intact $L$. hohenwarti and subjects antennectomised above the 7 th segment.

\begin{tabular}{ccccc}
\hline $\begin{array}{c}\text { R.H. } \\
\begin{array}{c}\text { alternatives } \\
\text { (in \%) }\end{array}\end{array}$ & $\begin{array}{c}\text { Subjects antennectomised } \\
\text { above 7th segment } \\
\text { vs intact subs. }\end{array}$ & $\begin{array}{c}\text { Subjects antennectomised } \\
\text { above 7th segment } \\
\text { vs control subs. }\end{array}$ \\
\cline { 2 - 5 } & $\mathrm{t}$ & Significance & $\mathrm{t}$ & Significance \\
\hline $20-100$ & 14.472 & $\mathrm{P}<0.001$ & 5.970 & $\mathrm{P}<0.001$ \\
$50-100$ & 0.472 & $0.9>\mathrm{P}>0.5$ & 4.230 & $0.01>\mathrm{P}>0.001$ \\
$90-100$ & 6.809 & $\mathrm{P}<0.001$ & 0.980 & $0.4>\mathrm{P}>0.2$ \\
$50-90$ & 8.856 & $\mathrm{P}<0.001$ & 3.093 & $0.02>\mathrm{P}>0.01$ \\
\hline
\end{tabular}

The experiments conducted on Bathysciola confirm the above results and the role of antenna receptors in humidity response. Similarly, the reaction of integral subjects was significantly different from the reaction displayed by antennectomised or control subjects.

Experiments on Leptodirus subjects antennectomised above the 7th antenna 
Table 6. Significance, $\mathrm{P}$, of the humidity responses of antennectomised $L$. hohenwarti.

Reactions of subjects antennectomised above and below the 7 th segment are compared.

\begin{tabular}{ccc}
\hline $\begin{array}{c}\text { R.H. alternatives } \\
\text { (in \%) }\end{array}$ & $\mathrm{t}$ & Significance \\
\hline $20-100$ & 8.226 & $\mathrm{P}<0.001$ \\
$50-100$ & 7.925 & $\mathrm{P}<0.001$ \\
$90-100$ & 0.969 & $0.4>\mathrm{P}>0.2$ \\
$50-90$ & 5.390 & $\mathrm{P}<0.001$ \\
\hline
\end{tabular}

segment show instead that the insects react to the stimulus, though response intensity in these cases is not as high as that for integral subjects. This would seem to indicate that receptors on the 7 th, 9 th and 10th antenna segment play an additive role in perception. Only in experiments with a $90-100 \%$ relative humidity was insect reaction similar to that exhibited by control subjects and by subjects antennectomised below the 7 th antenna segment.

\section{DISCUSSION}

The results reported above show clearly that important humidity receptors are situated on the 7 th, 9th and 10th segments of the Bathysciinae antennae. It seems therefore, quite probable that the antennal organs situated on said segments and described by Jeannel (1911), Baccetti and Sbordoni(1967), CorbièreTichané (1974) and Accordi and Sbordoni (1978) may be attributed with a role in humidity reception. At the same time, these results would seem to exclude the presence of any other humidity receptors in the Bathysciinae.

Little is currently known about humidity receptors in insects and on how they work (Pielou, 1940; Wigglesworth, 1941; Lees, 1943; Roth and Willis, 1951; Benz, 1955; Bursell, 1957; Waldow, 1970; Arbogast, Roppel and Carthorn, 1972; Altner, Saas and Altner, 1977). Foelix and Axtell (1972) attribute a humidity receptor role to the coeloconic sensilla of Amblyomma americanum. These sensilla do not seem to be very different from those found in Bathysciinae but are structurally some what less complex. Of all the various structure that make up the antennal organ, probably only the cribrose ones (according to Accordi and Sbordoni, 1978) are engaged in humidity reception because they are common to the 7 th, 9th and 10th antenna segments.

The considerable structural complexity and significant differences between the Bathysciola and Leptodirus antennal organs which do not seem to correspond to a similar difference in humidity reaction could indicate that the Bathysciinae antennal organs may have other sense roles such as chemioreception as already suggested by Jeannel. 


\section{ACKNOWLEDGEMENTS}

We wish to express our gratitude to Roberto Argano and Marina Cobolli Sbordoni who collaborated with the senior author (V.S.) in the early experiments on humidity reactions of Bathysciinae. We are also indebted to G. M. Carchini, M. Rampini, M. Di Rao and A. Di Tosto for their friendly assistance in collecting Leptodirus specimens. Elena Semeraro Gilardi helped in the preparation of illustrations.

\section{SUMMARY}

The humidity responses of Bathysciola derosasi and Leptodirus hohenwarti, two species of troglobitic Bathysciinae showing different degrees of adaptation to cave environment, have been studied. Intact and antennectomised subjects were tested using choice-chambers with various combinations of relative humidity alternatives (i.e. $20-100 \%, 50-100 \%, 90-100 \%, 50-90 \%$ and, as controls, $100-100 \%$ ) to investigate the role played by the sense organs situated on the 7 th, 9 th and 10 th antenna segments.

The results show that intact-antenna subjects of both species are very sensitive to humidity gradients and that their intensity of reaction varies according to the intensity of stimulus, as previously reported by Argano, Sbordoni and Cobolli Sbordoni (1969). The antennectomy experiments show that receptors situated on the 7th, 9th and 10th antenna segments (Hamann's organ) are involved in hygroreception. In Leptodirus, insects antennectomised below the 9th segment show a reduced intensity of reaction, while those antennectomised below the 7 th segment show no positive response at all. This seem to indicate that receptors in the 9 th and 10 th antennal segments have additive roles beyond that of the 7 th. Further research is needed to ascertain whether the antennal organs of Bathysciinae may have yet further additional sensory roles (e.g. chemioreception) as their complex structure suggests.

\section{RIASSUNTO}

Nel presente lavoro vengono analizzate le risposte a differenti condizioni alternative di umidità relativa $(20-100 \%, 50-100 \%, 90-100 \%, 50-90 \%$ e controlli: $100-100 \%)$ in due specie di Coleotteri Batiscini troglobi caratterizzati da diverso livello di specializzazione morfo-fisiologica, Bathysciola derosasi, e Leptodirus hohenwarti. In entrambe le specie viene confrontata la risposta di individui integri e antennoctomizzati per chiarire il ruolo degli organi sensoriali (organi di Hamann) presenti sul $7^{\circ}, 9^{\circ}$ e $10^{\circ}$ antennomero.

I risultati mostrano che gli individui integri di entrambe le specie sono molto sensibili all'umidità reagendo positivamente alle condizioni di stimolo proposte e che la loro intensità di reazione varia secondo l'intensità dello stimolo. Gli individui di entrambe le specie antennoctomizzati sotto il $7^{\circ}$ antennomero non mostrano, al contrario, risposte positive e, in generale, non significativamente diverse da quelle manifestate da soggetti integri in esperimenti di controllo (con umidità alternative 100-100\%). Inoltre, individui di Leptodirus hohenwarti, antennoctomizzati tra il $7^{\circ} \mathrm{e}$ il $9^{\circ}$ antennomero mostrano una intensità di reazione ridotta rispetto ai soggetti integri, ma significativamente diversa dai controlli.

Questi risultati suggeriscono un ruolo additivo dei recettori situati sul $7^{\circ}, 9^{\circ}$ e $10^{\circ}$ segmento antennale, e confermano l'ipotesi del ruolo igrorecettivo dell'organo di Hamann.

\section{REFERENCES}

ACCORDI, F. and V. SBORDONI, 1978. The fine structure of Hamann's organ in Leptodirus hohenwarti, a highly specialized cave Bathysciinae (Coleoptera Catopidae). Int. J. Speleol. 9: 153-165. 
ALTNER, H., H. SASS and I. ALTNER, 1977. Relationship between structure and function of antennal chemo-, hygro-, and thermoreceptive sensilla in Periplaneta americana. Cell Tiss. Res. 176: 389-405.

ARBOGAST, R. T., R. M. ROPPEL and M. CARTHON, 1972. Hygroreceptors of adult sawtoothed grain beetles Oryzaephilus surinamensis (L.) (Coleoptera Cucujidae). Can. J. Zool. 50: 1147-1153.

ARGANO, R., V. SBORDONI and M. COBOLLI SBORDONI, 1969. The humidity responses of troglobitic Bathysciinae (Coleoptera Catopidae) at various degrees of specialization. 5. Int. Kongr. Speläologie Stuttgart 1969, Abh. München, 4: B 26/1.

BACCETTI, B. and V. SBORDONI, 1967. Prime osservazioni ultrastrutturali sull'organo antennale dei Bathysciinae. Boll. Zool. 34: 84-85.

BENZ, G., 1955. Zur Funktion einiger Sinnesorgane bei Larven von Drosophila melanogaster. Rev. Suisse Zool. 62: 305-313.

BULL, E. and R. W. MITCHELL, 1972. Temperature and relative humidity responses of two Texas cave-adapted millipedes, Cambala speobia (Cambalida: Cambalidae) and Speodesmus bicornourus (Polydesmida: Vanhoeffeniidae). Int. J. Speleol. 4: 365-393.

BURSELL, E., 1957. Humidity receptors in thoracic spiracles of Glossina. J. exp. Biol. 34 (1): $42-51$.

BUXTON, P. A. and K. MEllanBY, 1934. The measurement and control of humidity. Bull. Ent. Res. 25: 171-175.

CORBIERE-TICHANÉ, G., 1974. Fine structure of an antennal sensory organ ("vésicule olfactive") of Speophyes lucidulus Delar. (cave Coleoptera of the Bathysciinae subfamily). Tissue \& Cell 6 (3): 535-550.

CORBIËRE-TICHANÉ, G., 1977. Étude comparative au microscope électronique de la "vésicule olfactive” des Catopidae cavernicoles (Coléoptères). Ann. Sci. Nat., Zoologie, Paris (12) 19: 89-110.

FOELIX, R. F. and R. C. AXTELL, 1972. Ultrastructure of Haller's organ in the tick Amblyomma americanum (L.). Z. Zellforsch. 124: 275-292.

FRAENKEL, G. S. and D. L. GUNN, 1961. The orientation of animals. Kineses, taxes and compass reactions. Dover Inc. New York.

GUNN, D. L. and J. S. KENNEDY, 1936. Apparatus for investigating the reactions of land arthropods to humidity. J. exp. Biol. 13: 450-459.

JEANNEL, R., 1911. Biospeologica XIX. Revision des Bathysciinae (Coléoptères Silphides). Arch. Zool. exp. et gén. (5) 7: 1-641.

LEES, A. D., 1943. On the behaviour of wireworms of the genus Agristes. J. exp. Biol. 20 (1): 43-53.

PATRIZI, S., 1956. Introduzione e acclimatazione del coleottero Bathysciola derosasi Dod. in una grotta laziale. Le Grotte d'Italia (3) 1: 303.

PECK, S. B., 1977. An unusual sense receptor in internal antennal vesicles of Ptomaphagus (Coleoptera Leiodidae). Can. Ent. 109: 81-86.

PERTUNNEN, V., 1973. Individual variation in the responses of Rhizopertha dominica F. (Coleoptera Bostrychidae) to air humidity and light. Ann. Ent. Fenn. 39 (3): 129-142.

PIELOU, D. P., 1940. The humidity behaviour of the mealworm beetle Tenebrio molitor L. II. The humidity receptors. J. exp. Biol. 17: 295-306.

PIELOU, D. P. and D. L. GUNN, 1940. The humidity behaviour of the mealworm beetle Tenebrio molitor L. I. The reaction to difference of humidity. J. exp. Biol. 17: 286-294.

ROTH, L. M. and E. R. WILLIS, 1951. Hygroreceptors in Coleoptera. J. exp. Zool. 117: 451-484.

SBORDONI, V. and M. COBOLLI, 1969. Note sull'allevamento sperimentale degli animali cavernicoli in laboratorio. Arch. Zool. It. 54: 33-57.

SBORDONI, V. and M. COBOLLI SBORDONI, 1973. Aspetti ecologici ed evolutivi del popolamento di grotte temperate e tropicali: osservazioni sul ciclo biologico di alcune specie di Ptomaphagus (Coleoptera Catopidae). Int. J. Speleol. 5: 337-347.

WALDOW, U., 1970. Elektrophysiologische Untersuchungen an Feuchte-, Trocken- und Kälterezeptoren auf der Antenne der Wanderheuschrecke Locusta. Z. vergl. Physiologie 69: 249-283.

WIGGLESWORTH, V. B., 1941. The sensory physiology of the human louse Pediculus humanus corporis De Geer (Anoplura). Parasitology 33: 67-109. 